\title{
『プラサンナパダー』における 『中論』偈頌の形態について
}

\section{王 俊 淇}

はじめに 七世紀頃の中観思想家チャンドラキールティ（Candrakīrti）が著した 『プラサンナパダー』(Prasannapadā) は『中論』（Mūlamadhyamakakārikāa, MMK）の注釈 書の中でサンスクリット完本が現存する唯一の文献である。本稿は『プラサンナ パダー』における『中論』偈頌を次の二種類に大別する，第一に，『プラサンナ パダー』は『中論』注橎書として，その構成に従い，順次に『中論』偈頌を引用 し，注釈を施している。本稿では，このような『中論』偈頌を「基本型」と呼 ぶ、第二に，チャンドラキールティはある思想を説明するために, 『中論』の偈 頌を適宜援用する場合がある。この援用された偈頌を基本型と比べると，異読を 含む例が少なくない，本稿では，異読が見られる援用偈頌を「变異型」と呼ぶ.

変異型は『プラサンナパダー』の校訂のみならず，そこに引用される『中論』 偈頌のテキストを確定するうえでも，無視できないものである。本稿は『プラサ ンナパダー』における変異型の例を抜き出し，『プラサンナパダー』写本 ${ }^{1)}$ を参 照しながら，これらを分析する。

『中論』偈頌の変異型『プラサンナパダー』全体にわたって, 以下の7つの変 異型の例が回収できる。（太字は基本型と相違する箇所）

1. bhaved abhāvo bhāvaś ca nirvāṇam ubhayam katham | asaṃskṛtaṃ ca nirvāṇam bhāvābhāvau ca saṃskṛtau || MMK 25.13 (LVP, p. 531); bhaved abhāvo bhāvaś ca nirvāṇam ubhayam katham | na saṃskṛtaṃ hi nirvāṇam bhāvābhāvau ca saṃskṛtau $\|$ MK 25.13 (LVP, p. 175)

2. nāpy abhūtvā samudbhūto doṣo hy atra prasajyate $\mid$ krtako vā bhaved ātmā sambhūto vāpy ahetukaḥ || MMK 27.12 (LVP, p. 580); nāpy abhūtvā samutpanno doṣo hy atra prasajyate | kṛtako vā bhaved ătmā sambhūto vāpy ahetukah $\| \doteqdot$ MMK 27.12 (LVP, p. 341)

3. buddhair nātmā na cānātmā kaścid ity api deśitam \| MMK 18.6cd (LVP, p. 355); buddhair ātmā na cānātmā kaścid ity api deśitam $\| \doteqdot$ MMK 18.6cd（LVP, p. 358）

4. utpādasthitibhangānām asiddher nāsti samskṛtam | saṃskṛtasyāprasiddhau ca katham setsyaty asaṃskṛtam || MMK 7.33 (LVP, p. 176); utpādasthitibhan̉gānām asiddhau nāsti saṃskṛtam 
saṃskṛtasyāpy asiddhau ca katham setsyaty asaṃskṛtam $\| \doteqdot$ MMK 7.33（LVP, p. 386)

5. āgacchaty anyato nāgnir indhane 'gnir na vidyate $\mid$ MMK 10.13ab (LVP, p. 210); āgacchaty anyato nāgnir na vidyate tathendhane $\mid \fallingdotseq$ MMK 10.13ab (LVP, p. 391)

6. yadi śūnyam idaṃ sarvam udayo nāsti na vyayaḥ $\mid$ MMK 24.1ab (LVP, p. 475); yadi sarvam idam śūnyam udayo nāsti na vyayaḥ $\mid \doteqdot$ MMK 24.1ab (LVP, p. 490)

7. yena grāho gṛhītas tu ghano 'stīti tathāgatạ̣ | nāstīti sa vikalpayan nirvṛtasyāpi kalpayet $\|$ MMK 22.13 (LVP, p. 447); ghanagrāhagṛhītas tu yenāstīti tathāgatạ̣ | nāstīti vā kalpayan sa nirvṛtasya vikalpayet $\| \doteqdot$ MMK 22.13 (LVP, p. 534)

考証 このうち, 1-3と6の変異型は, 今回の調査対象とした六種の写本すべて に見られるので2)，校訂テキストの誤りというわけではない．また『プラサンナ パダー』の文脈から，チャンドラキールティは明らかに，これらを『中論』の偈 頌と見なしている。しかし, 彼がこれらの偈頌を援用する際, 本来の偈頌の形を 書き換える必要性があったとは考え難い ${ }^{3)}$. 第4例の変異型に関しては，まず写 本には asiddhe（RTC）と asiddher（N）の異読がある。基本型の “asiddhau”とあわ せて考えると, 変異型については asiddhau $>$ asiddhe $>$ asiddher の成立過程が予想で きる. また, “....āpy asiddhau”は六種の写本すべてに見られるので, 変異型の形 と判断して間違いない.

第5の例に関しては，TCN 三写本は変異型を伝えているが， $\mathrm{R}$ 写本は基本型と 同じ形を保っている. そのため, この援用偈頌（LVP, p. 391）はそもそも変異型で はなく, 基本型と同じ形であっただろう.

第7の例は基本型と変異型で大きく異なるが, 写本とチベット語訳を参照する と, いずれも de La Vallée Poussin 本のテキストを訂正する必要が認められる. 再 校訂の結果を示すと，基本型は “ghanagrāho gṛhītas tu yenāstīit tathāgatạ | nāstīti vā vikalpam sa nirvṛtasyāpi kalpayet $\|^{4)}$ ” となり, 変異型は “ghanagrāho grhītas tu yenāstīti tathāgatah $\mid$ nāstīti vā vikalpạ̣ sa nirvṛtasya vikalpayet $\|^{5) ” と な る ． こ の よ う ~}$ に訂正すると，両者は偈頌の末尾にのみ，違いが見られることになる．すなわち 基本型の “api kalpayet”と変異型の“-a vikalpayet”が相違するに過ぎない.

1と3-7の六例に関しては, 相違は軽微で, 写本伝写の過程で生じた誤写と見 なすこともできる，それに対して 2 は偈頌の前後の注釈に影響され，その内容が 偈頌に反映された可能性は否定できない6).

『中論』偈頌の変異型は，本来の『中論』頌の形態を考えるうえで貴重な資料 であるが, 少なくとも『プラサンナパダー』の校訂の際には, すべての写本が変 
異型を支持しているのであれば，あえて基本型に合わせて変異型を訂正すること は避けるべきであろう。逆に，『中論』偈頌を回収する際に，変異型にもとづい て基本型を訂正することにも慎重な配慮を要しょう。

1）本稿で用いた『プラサンナパダー』写本の略号と目録番号は以下の通り. P: Potala Palace Manuscript (Yonezawa [2005]) Chap. 25; O: Oxford, Bodleian Library 1440-Ms. Sansk. a. 9 (R) ; R: Keshar Library No. 9-182= NGMPP reel. C19/8; T: Tokyo University Library No. 251; C: Cambridge University Library Add. 1483; N: NGMPP reel. E1294/03. MacDonald (2015: 88) によると, 現存十数点の『プラサンナパダー』写本の中で, この六種の写本は良質とさ れる。

2) 1. Ø O; na samskrtam hi RTCN（R28a5; T67b4-5; C51b1; N56a7-8）; 2. Ø O; samutpanno PRTCN (P47a; R59a4; T133a1; C98a2; N112b2); 3. Ø O; ātmā PRTCN (P49b; R62a7; T139b1; C102b2; N118a5) ; 4. Ø O; asiddhe...samskṛtasyāpy asiddhau RTC; asiddher... saṃskṛtasyāpy asiddhau N (R69a12; T152a5; C111a1-2; N129b2-3) ; 5. Ø O; indhane 'gnir na vidyate R; na vidyate tathendhana TCN（R70a6-7; T154a1; C112a6; N131a1）；6. Ø O; sarvam idam śūnyam RTCN（R91a6-7; T196b3; C145a3; N167b9).

3）『プラサンナパダー』において，チャンドラキールティが意図的に『中論』の偈頌を改 作した詩頌がある。例えば, “aniruddho nirodho ’yam svātmānam nāśayet katham $\mid$ atha nașto nāśayati naște kị̣ nāśyate punạ̣ ||” (LVP, p. 171) という詩頌は “anutpanno ’yam utpādạ̣ svātmānam janayet katham | athotpanno janayate jāte kim janyate punah $\|$ MMK 7.13”にもとづい てチャンドラキールティの作ったものであろう。これは変異型の偈頌と明らかに異なっ ている.

4）前半偈の修正は de Jong（1978: 237）による，後半偈の校訂は，以下の四点を根拠とす る。第一に “vā”が ORTCNの五写本に見られる。第二に, “yena”の相関辞 (correlative) としての“sa” (=de Tib.) が期待される. 第三に, MMK 22.13基本型のチベット語訳は “med ces rnam rtog”とある。第四に, 変異型（P）に確認される“vikalpam”が基本型にお いても本来の語形であったと推測される. O86b3-4: Ø gṛhītas tu yenāstīti tathāgatah | nāstīti vā vikalpayan sa nirvṛttasyāpi kalpayet $\|$; R81b7: ghanagrāho gṛhìtas tu yenāstīti tathāgataḥ | nāstīti vā vikalpayan nirvṛtasyāpi kalpayet $\|$; T177a5-6, C129b7-8, N151a6-7: yena grāho gṛhītas tu yenāstìti tathāgatạ | nāstīti vā vikalpayan nirvṛtasyāpi kalpayet ||. MacDonald（2007: 42） は韻律 と変異型に基づいて，この偈頌を “ghanagrāho grhītas tu yenāstīti tathāgatạ | nāstīti vā kalpayan sa nirvrtasya vikalpayet || と読む. 同研究によれば，米澤嘉康氏の情報では，P写本の MMK 22.13 後半は “nāstīti sa vā vikalpam sa nirvrtasya vikalpayet”（17音節）とある．筆者が再度米 澤氏に確認した P 写本の MMK 22.13 基本型は以下の通り。“ghanagrāho gṛītas tu yenāstīti tathāgatạ | nāstīti vā vikalpam sa nirvrtasyāpi kalpayet ||”。これは本稿の推定した MMK 22.13 の形と一致している.

基本型のチベット語訳は以下の通り。“gang gis de bzhin gshegs yod ces || 'dzin pa stug pos bzung gyur pa $\|$ de ni nya ngan 'das pa la $\|$ med ces rnam rtog rtog par byed ||" (D 145b7; P 165b8)

基本型についてのチャンドラキールティの注釈は以下の通りである。“yena hi ghanataro mahatābhiniveśenāsti tathāgata iti grāho gṛhītaḥ parikalpa utpāditạ̣ | sa niyatạ̣ parinirvṛte tathāgate na bhavati tathāgatạ̣ param maraṇān maraṇād uttarakālaṃ na bhavaty ucchinnas tathāgato na samvidyata iti parikalpayet | PsP Chap. 22（LVP, p. 447）”【試訳】なぜなら，大執着 を持つある人が「如来が存在する」という非常に堅固な執着を捉え, つまり構想を生じ 
るならば，彼は必ずすでに般涅槃した如来に対して，「死んだ後に如来は存在しない」， 「死んだ後の時間に存在しない」，「[如来は］断滅する」，「如来はありえない」というよ うに構想する.

5) P76b6: ghanagrāho gṛhītas tu yenāstîti tathāgatạ̣ | nāstīti vā vikalpaṃ sa nirvṛtasya vikalpayet $\|$; O105a6: ghanagrāho gṛhītas tu yenāstīti tathāgatạ̣ | nāstīti $\varnothing$; R100a8: ghanagrāho gṛhītas tu yenāstîti tathāgatah | nāstīti cā kalpayana sa nirvatasya vikalpayet ||; T216a4; C159b5-6; N185a7-8: ghanagrāho gṛhītas tu yenāstīti tathāgatạ̣ | nāstīti vā kalpayan sa nirvṛtasya vikalpayet $\|$.

変異型のチベット語訳は以下の通り。“gang gis ’dzin stug bzung gyur pa $\|$ de ni mya ngan ’das pa la $\|$ de bzhin gshegs pa yod ce 'am $\|$ med ces rnam rtog rtog par byed \| (D 179b4-5; P 203a34)”このチベット語訳は Klu’i rgyal mtshanによって訳されたAkutobhayā, Prajñāpradīpa, Prajñāpradīpațīkāの MMK 22.13 と同じである（叶 $[2011,376]$ ). また, この変異型におけ る vikalpam ... vikalpayet は cognate object（cognate accusative）である.これはこの偈蕦の 本来の形であったはずだろう.

変異型について, チャンドラキールティの注勫は以下のようである。“evam tāvat param nirodhād bhavati tathāgato na bhavati ceti nohyate | etad dvayasyābhāvād ubhayam ity api nohyate, ubhayasyābhāvād eva nobhayam iti nohyate na grhyate \| PsP Chap. 25（LVP, p. 534）【【試訳】以 上のように，まず，滅の後に如来が存在するとも，存在しないとも表現されない。二者 がないから，この二者であるとも表現されない. 二者がないからこそ，二者でないとも 表現されず，把握されない.

Nyi ma grags の訳は両章で異なり, 著者の異なる解釈を適切に反映していると考えられる.

6） $\fallingdotseq$ MMK 27.12 の導入部分： tatra yadi skandhā ātmeti parikalpyate tadodayavyayabhāg utpādī ca vināśī cātmā prāpnoti skandhānām udayavyayabhāktvāt na cāivam iṣyate ātmā anekadoșaprasangāt $\mid$ PsP Chap. 18 (LVP, p. 341).

\section{〈略号表〉}

MMK Mūlamadhyamakakārikā. PsP Prasannapadā. LVP de La Vallée Poussin (1903-1913).

\section{〈一次資料〉}

Mūlamadhyamakakārikās (Mādhyamikasūtras) de Nāgārjuna avec la Prasannapadā commentaire de Candrakìti. Ed. Louis de La Vallée Poussin. Bibliotheca Buddhica Series, no. 4. St. Pétersbourg: Commissionnaires de l'Académie impériale des Sciences, 1903-1913. In Clear Words: The Prasannapadā, Chapter One Vol. I: Introduction, Manuscript Description, Sanskrit Text. Ed. Anne MacDonald. Wien: Verlag der Österreichischen Akademie der Wissenschaften, 2015. Zhonglun song 中論頌. Ed. Ye Shaoyong 叶少勇. Shanghai: Zhongxi Book Company, 2011.

\section{〈二次資料〉}

de Jong, J. W. 1978. “Textcritical Notes on the Prasannapadā.” Indo-Iranian Journal 20: 25-59, $217-$ 252. MacDonald, Anne. 2007. "Revisiting the Mūlamadhyamakakārikā: Text-Critical Proposals and Problems." Studies in Indian Philosophy and Buddhism 14: 25-55. Yonezawa, Yoshiyasu. 2005. “*Lakṣaṇatịkā: Sanskrit Notes on the Prasannapadā (2).” Journal of Naritasan Institute for Buddhist Studies 28: 159-179.

$$
\text { 〈キーワード〉 プラサンナパダー, 中論, 偈頌, 写本 }
$$

